\title{
HUBUNGAN LINGKUNGAN KELUARGA DENGAN PRESTASI BELAJAR SISWA KELAS IV SD NEGERI SEKECAMATAN KEBUMEN TAHUN AJARAN 2020/2021
}

\author{
Irfan Yoni Tama ${ }^{1}$, Suhartono ${ }^{2}$, Tri Saptuti Susiani ${ }^{3}$ \\ Universitas Sebelas Maret \\ irfan.yonitama@gmail.com
}

\section{Article History}

accepted 1/11/2021

approved $1 / 12 / 2021$

published 31/12/2021

\begin{abstract}
Family environment is the most important thing for student's educational improvement because Family environment is the first place for a student to communicate and socialize. The study aimed to analyze the correlation and contribution of family environment on mathematics learning achievement to fourth grade students of public elementary schools in Kebumen Subdistrict in academic year of 2020/2021. The research uses a quantitative approach with the correlation method. Analysis uses a simple correlation analysis. Population of this study amounted to 1,400 students with a sample of 327 fourth grade students of public elementary school in Kebumen Sub-district. The results showed that the family environment and student's mathematics learning achievement had a correlation coefficient of 0.412. Family environment contributed $16.9 \%$ on mathematics learning achievement and the remaining $83.1 \%$ was influenced by other factors. It concludes that there is positive correlation between family environment and mathematics learning achievement. This meant that the better student's family environment, the higher student's mathematics learning achievement, and vice versa.

Keywords: family environment, mathematics learning achievement
\end{abstract}

\begin{abstract}
Abstrak
Lingkungan keluarga menjadi lingkungan yang paling penting dalam perkembangan pendidikan seorang siswa dikarenakan keluarga merupakan tempat pertama kali seorang siswa untuk berkomunikasi dan melakukan sosialisasi. Penelitian ini bertujuan untuk menganalisis hubungan dan sumbangan lingkungan keluarga dengan prestasi belajar matematika siswa kelas IV SD Negeri se-Kecamatan Kebumen Tahun Ajaran 2020/2021. Penelitian ini menggunakan pendekatan kuantitatif dengan metode korelasi. Analisis yang digunakan yakni analisis korelasi sederhana. Populasi penelitian ini berjumlah 1.400 siswa dengan sampel 327 siswa kelas IV SD Negeri se-Kecamatan Kebumen. Hasil penelitian menunjukkan bahwa hubungan lingkungan keluarga dengan prestasi belajar matematika siswa memiliki koefisien korelasi sebesar 0,412 dan sumbangan sebesar $16,9 \%$. Berdasarkan pembahasan dan analisis data penelitian dapat disimpulkan bahwa hubungan lingkungan keluarga dengan prestasi belajar matematika siswa memiliki hubungan positif di mana semakin baik lingkungan keluarga siswa, maka akan semakin tinggi pula prestasi belajar matematika siswa, dan sebaliknya. Sumbangan hubungan lingkungan keluarga dengan prestasi belajar matematika siswa sebesar $16,9 \%$ dan $83,1 \%$ dipengaruhi faktor lain.
\end{abstract}

Kata kunci: lingkungan keluarga, prestasi belajar matematika 


\section{PENDAHULUAN}

Dewasa ini pada abad 21 ini pendidikan masih menjadi faktor penting dalam menjadi tolok ukur maju tidaknya suatu negara. Negara yang maju merupakan negara yang memiliki sumber daya manusia yang berkualitas karena dibentuk dengan pendidikan yang baik. Sumber daya manusia yang berkualitas tentunya harus memiliki keterampilan berpikir kritis, memecahkan masalah, berkomunikasi, berkolaborasi, kreatifitas, dan berinovasi. Menurut National Council of Teacher of Mathematics (Nahdi, 2019) pembelajaran matematika mengharuskan adanya keterampilan memecahkan masalah, menalar dan membuktikan, komunikasi, koneksi, dan representasi sehingga dalam pembelajaran matematika pun berkaitan erat dengan keterampilan abad-21.

Menurut Wahyudi (2015) matematika adalah bahan kajian yang dibangun berdasarkan penalaran deduktif, artinya kebenaran konsep didapatkan melalui akibat logis dari kebenaran sebelumnya. Matematika merupakan pelajaran yang sering dianggap sukar oleh siswa padahal tanpa kita sadari kita tidak dapat terlepas dari matematika dalam kehidupan kita karena matematika menjadi hal yang penting dan dibutuhkan kapan dan di mana saja dalam kehidupan (Novitasari, 2016).

Penguasaan matematika siswa di Indonesia masih tergolong rendah. Hal ini dapat dilihat dari penelitian PISA (The Programme for International Student Assessment), Indonesia menempati peringkat 62 dari 69 negara yang tergabung dalam OECD (Organisation of Economic Cooperation and Development) pada tahun 2015 (Pertiwi, 2019). Dalam mengukur keberhasilan pendidikan khususnya pembelajaran matematika tentunya dapat menggunakan prestasi belajar yang telah dicapai siswa. Semakin tinggi nilai prestasi belajar siswa maka semakin baik pula ukuran keberhasilan pendidikan. Syah (2015) berpendapat bahwa prestasi adalah tingkat keberhasilan dalam mencapai tujuan yang telah ditetapkan dalam sebuah program.

Lingkungan keluarga menjadi lingkungan yang paling penting dalam perkembangan pendidikan seorang siswa dikarenakan keluarga merupakan tempat pertama kali seorang siswa untuk berkomunikasi dan melakukan sosialisasi (Hanifah, Joharman, Suhartono, 2020). Sesuai dengan pendapat di atas Sagulu (2018) berpendapat bahwa lingkungan keluarga merupakan faktor lingkungan yang sangat berpengaruh terhadap pencapaian prestasi belajar siswa karena siswa merupakan bagian dari anggota keluarga dan selalu berinteraksi dengan keluarga terutama orang tua yang menyediakan fasilitas belajar.

Prestasi belajar siswa dipengaruhi oleh berbagai faktor baik yang berasal dari dalam diri maupun luar diri. Faktor yang berasal dari dalam diri (intern) terdiri dari faktor jasmaniah, misal faktor kesehatan dan cacat tubuh serta faktor psikologi, misal intelegensi, perhatian, minat, bakat, motif, kematangan dan kelelahan. Faktor yang berasal dari luar individu (ekstern) terdiri dari faktor keluarga, faktor sekolah, dan faktor masyarakat (Slameto, 2015).

Penelitian ini menggunakan pendapat Slameto sebagai indikator lingkungan keluarga. Menurut Slameto (2015) beberapa indikator lingkungan keluarga yang mampu mempengaruhi hasil belajar anak meliputi cara orang tua mendidik, hubungan antar anggota keluarga, suasana rumah, keadaan ekonomi keluarga, perhatian orang tua, dan latar belakang kebudayaan keluarga.

Berdasarkan uraian di atas, penelitian ini dilakukan dengan tujuan: (1) mengetahui adanya hubungan positif antara lingkungan keluarga dengan prestasi belajar matematika siswa kelas IV SDN se-Kecamatan Kebumen tahun ajaran 2020/2021, dan (2) mengetahui besarnya sumbangan variabel lingkungan keluarga terhadap prestasi belajar matematika siswa kelas IV SDN se-Kecamatan Kebumen tahun ajaran 2020/2021. 


\section{METODE}

Penelitian ini merupakan penelitian kuantitatif dengan metode korelasi. Penelitian korelasi menurut Purwanto (2012) adalah penelitian yang mengaitkan hubungan variabel satu dengan variabel yang lain. Dalam penelitian ini, peneliti mengaitkan hubungan antara lingkungan keluarga dan prestasi belajar matematika siswa kelas IV.

Populasi penelitian ini yaitu siswa kelas IV SDN se-Kecamatan Kebumen sejumlah 1400 siswa, sampel sebanyak 312 siswa, dan sampel yang diperoleh sebanyak 327 siswa di 13 SD Negeri di Kecamatan Kebumen yang dipilih secara acak dengan teknik cluster random sampling dengan bantuan aplikasi Statistical Product and Service Solution (SPSS) versi 21.

Teknik pengumpulan data penelitian ini menggunakan angket dan dokumen. Instrumen yang digunakan yaitu angket lingkungan keluarga meliputi indikator cara orang tua mendidik, hubungan antar anggota keluarga, suasana rumah, keadaan ekonomi keluarga, perhatian orang tua, dan latar belakang kebudayaan keluarga. Sedangkan dokumen yang digunakan yaitu nilai rapor matematika siswa kelas IV semester I tahun ajaran 2020/2021.

Uji prasyarat data penelitian ini menggunakan uji liniearitas dan uji normalitas. Setelah memenuhi prasyarat, data dianalisis menggunakan uji korelasi sederhana dan koefisien determinasi.

\section{HASIL DAN PEMBAHASAN}

Table 1 akan memperlihatkan tentang hasil analisis uji normalitas prestasi belajar matematika dan angket lingkungan keluarga.

Tabel 1. Hasil Analisis Uji Normalitas Prestasi Belajar Matematika dan Angket Lingkungan Keluarga

\begin{tabular}{lcc}
\hline Hasil & $\begin{array}{c}\text { Lingkungan } \\
\text { Keluarga }\end{array}$ & $\begin{array}{c}\text { Prestasi Belajar } \\
\text { Matematika }\end{array}$ \\
\hline$N$ & 327 & 327 \\
\hline Kolmogorov-Smirnov Z & 1.167 & 0.896 \\
\hline Asymp. Sig. (2-tailed) & 0.131 & 0.398 \\
\hline
\end{tabular}

Penelitian dilakukan dengan memberikan angket lingkungan keluarga kepada siswa kelas IV di SD yang menjadi sampel penelitian dan meminta dokumen berupa nilai rapor matematika siswa. Uji prasyarat data pada penelitian ini telah terpenuhi yaitu data berdistribusi normal dan data linier.

Pada penelitian ini diperoleh nilai signifikansi uji normalitas signifikansi metode One Sample Kolmogorov-Smirnov sebesar 0,398 untuk data prestasi belajar matematika, dan 0,131 untuk lingkungan keluarga. Nilai signifikansi pada kedua variabel tersebut menunjukkan lebih besar dari 0,05 , sehingga data dikatakan berdistribusi normal. 
Tabel 2. Hasil Analisis Uji Linearitas Prestasi Belajar Matematika dan Angket Lingkungan Keluarga

\begin{tabular}{|c|c|c|c|c|c|c|c|}
\hline \multicolumn{8}{|c|}{ ANOVA Table } \\
\hline & & & Sum of & & Mean & & \\
\hline & & & Squares & $d f$ & Square & $F$ & Sig. \\
\hline \multirow{7}{*}{$\begin{array}{l}\text { Prestasi } \\
\text { Belajar } \\
\text { Matematika* } \\
\text { Lingkungan } \\
\text { Keluarga }\end{array}$} & Between & (Combined) & 5468.621 & 33 & 165.716 & 3.146 & .000 \\
\hline & Groups & Linearity & 3341.057 & 1 & 3341.057 & 68.868 & .000 \\
\hline & & Deviation & 2127.564 & 32 & 66.486 & 1.370 & .094 \\
\hline & & from & & & & & \\
\hline & & Linearity & & & & & \\
\hline & Within $\mathrm{G}$ & oups & 14214.645 & 293 & 48.514 & & \\
\hline & Total & & 19683.266 & 326 & & & \\
\hline
\end{tabular}

Berdasarkan uji linearitas diperoleh nilai Sig. Deviation from Linearity untuk variabel lingkngan keluarga terhadap prestasi belajar matematika adalah 0,094. Nilai Sig. Deviataion from Linearity menunjukkan $>(0,05)$. Oleh karena itu data penelitian ini bersifat linier.

Setelah uji prasyarat analisis data telah terpenuhi, selanjutnya dilakukan analisis data uji hipotesis.

Tabel 3. Hasil Analisis Korelasi Sederhana Prestasi Belajar Matematika dan Angket Lingkungan Keluarga

\begin{tabular}{llrr}
\hline \multicolumn{3}{c}{ Correlations } \\
\hline & \multicolumn{1}{c}{$\begin{array}{c}\text { Lingkungan } \\
\text { Keluarga }\end{array}$} & $\begin{array}{c}\text { Prestasi Belajar } \\
\text { Matematika }\end{array}$ \\
\hline Lingkungan Keluarga & $\begin{array}{l}\text { Pearson } \\
\text { Correlation }\end{array}$ & 1 & $.412^{* *}$ \\
\cline { 2 - 4 } & Sig. (1-tailed) & 327 & .000 \\
\cline { 2 - 4 } & $\mathrm{N}$ & $.412^{* *}$ & 327 \\
\hline $\begin{array}{l}\text { Prestasi belajar } \\
\text { Matematika }\end{array}$ & $\begin{array}{l}\text { Pearson } \\
\text { Correlation }\end{array}$ & .000 & \\
\cline { 2 - 4 } & Sig. (1-tailed) & 327 & 327 \\
\cline { 2 - 4 } & $\mathrm{N}$ & 327 \\
\hline${ }^{* *}$. Correlation is significant at the 0.01 level (1-tailed). \\
\hline
\end{tabular}

Analisis hipotesis pada uji korelasi yaitu Ho pada penelitian ini tidak terdapat korelasi positif antara lingkungan keluarga terhadap prestasi belajar matematika siswa kelas IV SDN se-Kecamatan Kebumen tahun ajaran 2020/2021. Berdasarkan analisis yang telah dilakukan, diketahui nilai Sig. yaitu 0,000. Hal itu berarti nilai signifikansi $<\alpha \quad(0,000<$ 0,05 ), yang berarti bahwa Ho ditolak, sehingga dapat ditarik kesimpulan bahwa ada korelasi positif antara lingkungan keluarga dan prestasi belajar matematika siswa kelas IV SDN se-Kecamatan Kebumen. Sedangkan untuk hasil analisis korelasi antara variabel lingkungan keluarga dan prestasi belajar matematika didapatkan $r$ hitung sebesar 0,412 dengan $r$ tabel sebesar 0,108 . Oleh karena itu, nilai $r$ hitung $(0,412)>r$ tabel $(0,108)$ artinya terdapat hubungan positif antara lingkungan keluarga dan prestasi belajar matematika dengan koefisien korelasi tersebut berada pada tingkat hubungan sedang. Sesuai dengan penelitian Daryanti (2016) tentang "Hubungan Lingkungan Belajar dengan Prestasi Belajar Mahasiswa" yang menyatakan bahwa ada hubungan 
lingkungan belajar dan prestasi belajar mahasiswa, dengan nilai signifikansi 0,428 yang termasuk dalam tingkat kekuatan korelasi sedang. Hubungan bersifat positif di mana semakin baik lingkungan belajar maka semakin baik prestasi belajar.

Sebelum mencari koefisien determinasi, terlebih dahulu dicari nilai koefisien korelasinya melalui hasil output pada uji korelasi sederhana yang mana terdapat nilai $r$ hitung sebesar 0,412. Hasil koefisien korelasi tersebut, kemudian digunakan untuk mencari koefisien determinan dengan rumus $\mathrm{KP}=\mathrm{r}^{2} \times 100 \%$ sehingga didapatkan koefisien determinasi dalam persen yaitu 16,9\% dengan koefisien determinasi sebesar 0,169 . Oleh karena itu, dapat disimpulkan bahwa pada prestasi belajar di kelas IV SD se-Kecamatan Kebumen variabel lingkungan keluarga memberikan sumbangan sebesar $16,9 \%$ dan sisanya berasal dari faktor lain. Sesuai dengan penelitian Mubin (2018) tentang "Hubungan Lingkungan Keluarga terhadap Karakter Disiplin dan Prestasi Belajar Siswa Di MI Al Firdaus Lasem Sidayu Gresik" menyatakan bahwa nilai koefisien determinasi $\left(R^{2}\right)$ adalah sebesar 0,451. Arti dari koefisien ini adalah bahwa pengaruh yang diberikan oleh kombinasi variabel lingkungan keluarga dan kedisiplinan belajar terhadap pembentukan karakter adalah sebesar $45,1 \%$, sedangkan sisanya $54,9 \%$ dipengaruhi oleh variabel lain.

\section{SIMPULAN}

Berdasarkan hasil penelitian mengenai lingkungan keluarga dan prestasi belajar matematika siswa kelas IV SDN se-Kecamatan Kebumen tahun ajaran 2020/2021 dapat disimpulkan bahwa: (1) Lingkungan keluarga berkorelasi positif terhadap prestasi belajar matematika siswa kelas IV SDN se-Kecamatan Kebumen tahun ajaran 2020/2021, dengan nilai koefisien korelasi 0,412 maka tingkat korelasi sedang yaitu semakin baik kualitas lingkungan keluarga siswa maka prestasi belajar matematika yang diperoleh juga akan semakin baik. (2) Sumbangan variabel lingkungan keluarga terhadap prestasi belajar matematika sebesar $16,9 \%$ dan sisanya $83,9 \%$ dipengaruhi oleh faktor lain.

Lingkungan keluarga berkorelasi positif terhadap prestasi belajar matematika siswa. Lingkungan keluarga merupakan faktor penting dalam perkembangan pendidikan siswa dan keluarga merupakan tempat pertama kali seorang siswa untuk berkomunikasi sekaligus melakukan sosialisasi. Hendaknya orang tua menciptakan kondisi lingkungan keluarga yang berkualitas supaya prestasi belajar matematika siswa dapat meningkat.

Lingkungan keluarga memberikan sumbangan terhadap prestasi belajar matematika siswa. Sehingga penting bagi guru untuk memasukkan indikator lingkungan keluarga dalam melaksanakan pembelajaran bagi siswa sehingga dapat berdampak positif pada siswa sehingga prestasi belajar siswa akan meningkat. Sekolah dan guru juga dapat berkoordinasi dengan orang tua siswa untuk membuat suatu acara keluarga yang dapat berdampak positif bagi kualitas lingkungan keluarga siswa.

Berdasarkan simpulan yang telah disebutkan, dapat diberikan beberapa saran yakni (1) Guru sebaiknya lebih memperhatikan pentingnya lingkungan keluarga pada saat memberikan pengajaran siswa. (2) Siswa sebaiknya turut serta dalam mengingatkan dan menciptakan lingkungan keluarga yang memiliki kualitas sehingga prestasi belajar matematika siswa dapat meningkat. (3) Sekolah hendaknya mampu memfasilitasi siswa dengan sarana dan prasarana yang baik sehingga prestasi belajar matematika yang lebih tinggi. (4) Bagi peneliti selanjutnya yang ingin melakukan penelitian yang hampir sama tentang hubungan lingkungan keluarga dengan prestasi belajar matematika siswa dapat menjadi acuan dalam penelitian korelasi dan mencari sumber referensi lainnya sehingga mampu melakukan penelitian yang lebih baik.

\section{DAFTAR PUSTAKA}


Daryanti, M. S. (2016). Hubungan Lingkungan Belajar dengan Prestasi Belajar Mahasiswa. Jurnal Kebidanan dan Keperawatan, Vol. 12, No.1.

Hanifah, U., Joharman., dan Suhartono. (2020). Hubungan antara Lingkungan Keluarga dan Hasil Belajar IPS Siswa Kelas V SDN Sekecamatan Ambal Tahun Ajaran 2019/2020. Kalam Cendekia: Jurnal IImiah Kependidikan ISSN: 2338-9400. Volume 8 Nomor 1 Tahun 2020.

Mubin, M. (2018). Hubungan Lingkungan Keluarga Terhadap Karakter Disiplin dan Prestasi Belajar Siswa di MI Al Firdaus Lasem Sidayu Gresik. At-Thullab: Jurnal Pendidikan Guru Madrasah Ibtidaiyah. Volume 2 Nomor 1. P-ISSN: 2579-625 eISSN: 2621-895X.

Nahdi, D. S. (2019). Keterampilan Matematika di Abad 21. Jurnal Cakrawala Pendas. Media Publikasi pada Bidang Pendidikan Dasar p-ISSN: 2442-7470 | e-ISSN: 2579-4442. Volume 5 Nomor 2 Edisi Juli 2019.

Novitasari, D. (2016). Pengaruh Penggunaan Multimedia Interaktif terhadap Kemampuan Pemahaman Konsep Matematis Siswa. Jurnal Pendidikan Matematika \& Matematika. Volume 2 Nomer 2 Edisi Desember 2016.

Pertiwi, I. (2019). Efek Program Pisa terhadap Kurikulum di Indonesia. Jurnal Pendidikan dan Kebudayaan. Pusat Penelitian Kebijakan Pendidikan dan Kebudayaan Badan Penelitian dan Pengembangan Kementerian Pendidikan dan Kebudayaan. Vol. 4, Nomor 1, Juni 2019.

Purwanto. (2012). Metodologi Penelitian Kuantitatif untuk Psikologi dan Pendidikan. Yogyakarta: Pustaka Pelajar.

Sagulu, K. Y. (2018). Pengaruh Disiplin Belajar dan Lingkungan Keluarga terhadap Hasil Belajar Siswa. Jurnal Pendidikan dan Ekonomi. Volume 7, Nomor 1, Tahun 2018. Slameto. (2015). Belajar dan Faktor-faktor yang Memengaruhi. Jakarta: Rineka Cipta. Syah, M. (2015). Psikologi Belajar. Jakarta: Rajawali Pers.

Wahyudi. (2015). Paduan Pembelajaran Matematika Sekolah Dasar. Surakarta: UNS PRESS. 